\title{
MONITORING SACCHAROMYCES CEREVISIAE POPULATIONS BY mtDNA RESTRICTION ANALYSIS AND OTHER MOLECULAR TYPING METHODS DURING SPONTANEOUS FERMENTATION FOR PRODUCTION OF THE ARTISANAL CACHAÇA
}

\author{
Roberta A.C. Araújo ${ }^{1}$; Fátima C.O. Gomes ${ }^{2}$; Elizabeth S.A. Moreira ${ }^{1}$; Patrícia S. Cisalpino ${ }^{1}$; Carlos A. Rosa ${ }^{1 *}$ \\ ${ }^{1}$ Departamento de Microbiologia, Instituto de Ciências Biológicas, Universidade Federal de Minas Gerais, Belo Horizonte, MG, \\ Brasil; ${ }^{2}$ Departamento de Química, Centro Federal de Educação Tecnológica, Belo Horizonte, MG, Brasil \\ Submitted: June 19, 2006; Returned to authors for corrections: August 24, 2006 Approved: February 12, 2007.
}

\begin{abstract}
An ecological study on Saccharomyces cerevisiae populations in spontaneous fermentation has been conducted in three vats of a cachaça distillery in Minas Gerais, Brazil. Ninety-seven yeast isolates were collected at the beginning, the middle and at the end of the production period, and were identified by standard methods. Differentiation between the indigenous $S$. cerevisiae strains isolated was performed by mitochondrial DNA (mtDNA) restriction analysis, RAPD-PCR, and PCR fingerprint using an intron splice primer. Analysis of the mtDNA restriction profiles revealed 12 different patterns, 11 corresponding to indigenous yeasts (I to XI) and one (XII) to a commercial strain of the bakery yeast. Pattern II (53.6\% of the population) and pattern IV strains were present in all the vats. Pattern IV strain raised from the middle to the end of the period reaching proportions near those of pattern II strain. PCR methods allowed the differentiation of 41 molecular profiles. Both methods showed population fluctuation of S. cerevisiae strains along the period of cachaça production and among different vats of the distillery.
\end{abstract}

Key words: Saccharomyces cerevisiae, cachaça, fermentation, molecular diversity

\section{INTRODUCTION}

Saccharomyces cerevisiae is the prevalent yeast species during the spontaneous fermentation of artisanal Brazilian cachaça $(5,9,12,19)$. The starter ferment is prepared by various methods, including the development of the fermentative microbiota in the sugar-cane juice alone, or mixing of sugarcane juice with crushed corn, rice or soy meal $(9,12)$. The identification and strain characterization of $S$. cerevisiae populations are of great importance to understand the cachaça fermentation process, since the quality of the beverage may depend upon the strains prevailing during the process, mainly in terms of their dynamics and occurrence $(10,11,12,13)$. Different techniques based on the detection of molecular polymorphism have been used for the characterization of cachaça yeast strains. Pulsed field gel electrophoresis (PFGE) allowed detecting the occurrence of different $S$. cerevisiae strains during the annual cycle of cachaça production (May to December), and even in different fermentation vats of the same distillery $(5,12)$. Although PFGE is a valuable method for discriminating strains, there are some factors that limit its applicability, since it is complex and time-consuming. Apart from this, the analysis of a large number of samples is difficult. A method of PCR fingerprinting developed by de Barros Lopes $(1,2)$, using an intron splicer primer, has proved useful to show the molecular diversity of $S$. cerevisiae strains isolated from different fermentative vats during cachaça production $(5,12)$. This method, associated with RAPD (randomly amplified polymorphic DNA)-PCR analysis, afforded the distinction among indigenous strains of S. cerevisiae during cachaça fermentation. Guerra et al. (5) suggested that the genetic diversity observed in S. cerevisiae populations may be the consequence of a large number of individual genotypes within the species. RAPD and PCR fingerprinting techniques are simple; yet, their reproducibility demands special care and occasionally the interpretation of results can be difficult $(4,5,20)$.

*Corresponding Author. Mailing address: Departamento de Microbiologia, ICB, C. P. 486, Universidade Federal de Minas Gerais, Belo Horizonte, MG, 31270-901, Brasil. Tel.: (31) 3499-2751 ou (31) 3499-2730. E-mail: carlrosa@icb.ufmg.br 
The mitochondrial DNA restriction analysis (mtDNA-RFLP) has been used by various authors to characterize and differentiate S. cerevisiae industrial strains $(6,8,14)$. mtDNA-RFLP is simple, reliable, fast and cost-effective, and has been reported to afford the differentiation among yeast strains isolated from the same must and to monitor the persistence and prevalence of a specific yeast strain during the whole fermentative process $(15-18,21,22)$. In the present study, we compare the use of mtDNA restriction analysis, RAPD-PCR, and PCR fingerprints for the molecular characterization of the prevalent $S$. cerevisiae populations in a distillery during the production period of the artisanal cachaça.

\section{MATERIALS AND METHODS}

\section{Yeast isolation and identification}

Samples were collected from three circular vats of 1,0001 of capacity (A, B and C) at the beginning (03/07/2000), the middle $(12 / 08 / 2000)$, and at the end (24/10/2000) of the annual cycle of cachaça production. The starter ferment was obtained by natural fermentation of the sugar-cane juice mixed crushed corn. The samples were collected during the tumultuous fermentation or at the end of the fermentative cycle. This distillery does not resort to centrifugation to carry out cell recycling, and the yeasts take on average $4 \mathrm{~h}$ to decant spontaneously, with the starter strain corresponding to $25 \%$ of the vat's volume. For the isolation of $S$. cerevisiae strains, serial 10 -fold dilutions of samples were made and $0.1 \mathrm{ml}$ inoculated in triplicate on SCY agar (sugarcane juice $10 \%$, yeast extract $0.5 \%$, agar $2 \%$, and chloramphenicol $0.01 \%$ ). Ten yeast colonies were selected representing the prevalent morphotype from each sample of the different vats, at the highest dilution plate. Also, at least one isolate of each distinct colony morphotype was collected for physiological and molecular characterization. The yeasts were identified by standard physiological tests (7).

\section{Mitochondrial DNA restriction analysis}

The mitochondrial DNA (mtDNA) was purified as described by Querol et al. (14), modified by López et al. (8). The mtDNA was digested with HinfI restriction endonuclease (Invitrogen), as prescribed by the manufacturer. The restriction fragments were separated by $1.0 \%$ agarose gel electrophoresis, with $1 \mathrm{X}$ TAE buffer (45 mmol $\mathrm{l}^{-1}$ Tris-borate, $1 \mathrm{mmol} \mathrm{l}^{-1}$ EDTA, $\mathrm{pH}$ 8), stained with ethidium bromide, visualized under UV-light and photographed.

\section{DNA extraction and PCR analysis}

Yeast DNA was extracted as described by Pataro et al. (12). For PCR fingerprinting, the primer EI1 (5'-CTGGCTTGGTG TGTATGT-3'), complementary to the intron consensus splicing sites, was used (1). For RAPD analysis, the primers OPA1 (5'CAGGCCCTTC-3'), and M13 (5'-GAGGGTGGCGGTTCT-3') (5) were used. The RAPD-PCR assay was performed in a 10-ml volume and the reaction mixture contained $1 \mathrm{ng}$ DNA template, $10 \mathrm{pmol}$ the primer, $1.5 \mathrm{mM} \mathrm{MgCl}_{2}, 50 \mathrm{mM} \mathrm{KCl}, 10 \mathrm{mM}$ of Tris/ $\mathrm{HCl} \mathrm{pH} \mathrm{8.5,} 125 \mathrm{Mm}$ dNTP's and 1.5 U Taq DNA polymerase. Reactions were carried out in a thermal cycler (model PTC 100, MJ Research, Inc). RAPD-PCR conditions were: 5 min at $95^{\circ} \mathrm{C}$ followed by two annealing cycles of $2 \mathrm{~min}$ at $30^{\circ} \mathrm{C}$, extension for $30 \mathrm{~s}$ at $72^{\circ} \mathrm{C}$ and denaturation for $30 \mathrm{~s}$ at $95^{\circ} \mathrm{C}$. Thirty-two additional annealing cycles of $2 \mathrm{~min}$ at $40^{\circ} \mathrm{C}$, extension of $30 \mathrm{~s}$ at $72^{\circ} \mathrm{C}$ and denaturation of $30 \mathrm{~s}$ at $95^{\circ} \mathrm{C}$ were also performed. After the last cycle, a final annealing of $2 \mathrm{~min}$ at $40^{\circ} \mathrm{C}$ and final extension of $5 \mathrm{~min}$ at $72^{\circ} \mathrm{C}$ were performed. PCR fingerprinting assays with primer EI1 were performed as described by Guerra et al. (5). PCR products were separated by agarose gel electrophoresis $(1.0 \%$, TAE $1 \mathrm{X}$ buffer), stained with ethidium bromide, visualized under UV-light and photographed. The phenetic analysis of RAPD and PCR fingerprinting results were made by comparing the number and sizes of DNA bands amplified from the various $S$. cerevisiae strains. The dendrogram was obtained by the Unweight Pair Group Method using Arithmetic Average (UPGMA) clustering algorithm, based on the data matrix constructed with the results of both the PCR methods combined, and built using the TFPGA (Tools for Population Genetic Analyses) computer package program.

\section{RESULTS AND DISCUSSION}

Saccharomyces cerevisiae was the only species isolated from the fermentation vats during the cachaça production period, with populations ranging between $5.0 \times 10^{6}$ and $3.39 \mathrm{x}$ $10^{9} \mathrm{cfu}^{\mathrm{ml}}{ }^{-1}$. The variations in $S$. cerevisiae may be explained by the circumstance as of sample collection, with higher counts observed during tumultuous fermentation and lower counts seen at the end of the fermentative cycle. Ninety-seven $S$. cerevisiae isolates were analyzed based on their mtDNA restriction patterns, RAPD and PCR fingerprinting profiles. Table 1 presents the $S$. cerevisiae morphotypes sampled, their mtDNA patterns, and estimate counts for the three vats at the beginning, the middle and at the end of the annual period of cachaça production. S. cerevisiae isolates with rough colonial texture and irregular margin were obtained from the three vats, with populations lower than $1.0 \times 10^{6} \mathrm{cfu} \cdot \mathrm{ml}^{-1}$, at the middle and the end of the production period.

The mtDNA restriction analysis provided 12 unique patterns for the 97 isolates that would therefore be considered as individual strains (Fig. 1). The strains presenting the mtDNARFLP patterns identified as II and IV were present in all the three vats during the fermentation season. Isolates showing the mtDNA pattern II (52 isolates) presented the highest yeast counts during the production period (Table 1, Fig. 2). It is worth noticing that $S$. cerevisiae strain, showing pattern IV, appeared at the middle of the period in all the three vats, and increased in vats $A$ and $B$ at the end of the fermentative period. Isolates that 


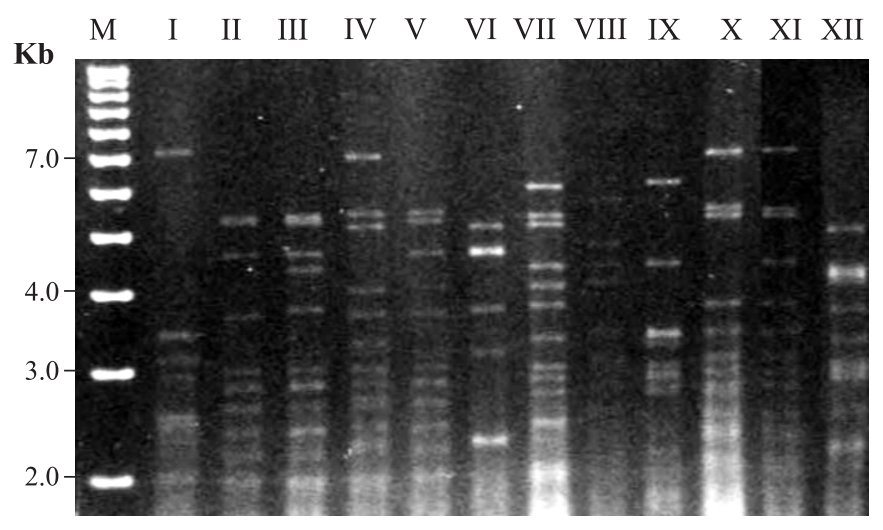

Figure 1. The twelve patterns generated by mtDNA-RFLP with HinfI restriction endonuclease of 97 Saccharomyces cerevisiae isolates from three fermentative vats (A, B and C) during the period for cachaça production. Lane Mw, $1 \mathrm{~kb}$ plus DNA Ladder (Gibco), I, UFMG-A2284; II, UFMG-A2415; III, UFMG-A2416; IV, UFMG-A2499; V, UFMG-A2256; VI, UFMG-A2426; VII, UFMG-A2430; VIII, UFMG-A2506; IX, UFMG-A2510; X, UFMG-A2514; XI, UFMG-A2394; XII, UFMG-A2517.

shared the rough colonial texture and irregular margin presented the same mtDNA restriction pattern (pattern IV) (Table1). The $S$. cerevisiae strain with pattern III was also present but in lower counts, in all the vats. The presence of pattern XII in vat $\mathrm{C}$ at the end of the season was a consequence of the addition of bakery yeast by the producer. This vat had problems in the must fermentation, specially concerning delays in the fermentative cycles, and the producer added bakery yeasts with a view to improving its fermentative performance.

The mtDNA-RFLP that, as far as we know, was applied here for the first time for studying the dynamic of $S$. cerevisiae populations involved in the cachaça fermentation, revealed high strain diversity, and indicated the predominance of two strains (patterns II and IV), in all vats (Fig. 2). This molecular technique allowed to correlate the morphotypes with rough colonial texture and irregular margins to a specific mtDNA restriction pattern (pattern IV) (Table 1, Fig. 1), although not all the isolates with this pattern exhibited rough colonies. Besides, mtDNA-RFLP was able to indicate the appearance of specific mtDNA patterns, suggesting that a succession of yeast strains would occur, and even that certain strains would prevail at the final stages of cachaça production.

RAPD analysis with primer M13 was not efficient to discriminate the $S$. cerevisiae strains (data not shown), and only the results obtained with primer OPA1 were used to differentiate the yeast strains. Figure 3 shows the results of RAPD with primer OPA1 and PCR fingerprinting analysis with primer EI1 for the $S$. cerevisiae isolates from each vat. The isolates were grouped in

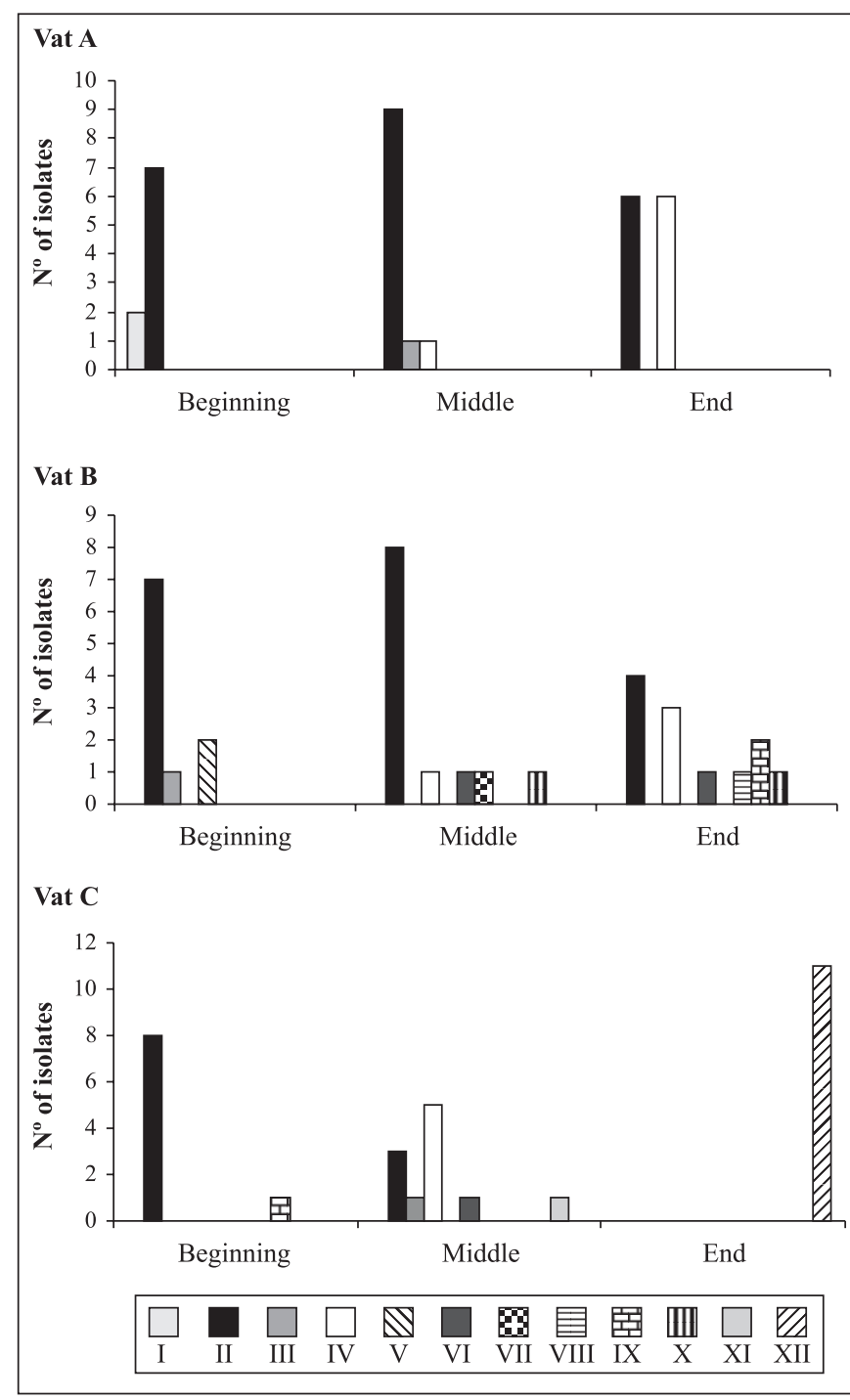

Figure 2. The occurrence of 12 Saccharomyces cerevisiae strains previously correlated to specific mtDNA restriction patterns in three fermentation vats (A, B, C) at the beginning, at the middle and at the end of the period for cachaça production.

distinct clusters, and the similarity was clearly associated with the production periods sampled. In vat A, four main clusters ('a', 'b', 'c', and 'd') were observed, corresponding to 17 different composite molecular patterns. Cluster 'a' comprised two molecular profiles with one isolate from the middle and the other from the end of the fermentative period, but both showing the same mtDNA restriction pattern (IV). Cluster ' $b$ ' was composed by nine isolates, all from the beginning of the season, with $70 \%$ similarity, corresponding to mtDNA patterns I and II. The mtDNA pattern I occurred exclusively in vat A, and was also signaled by an exclusive PCR profile (profile 6), which also occurred only in 
Table 1. Frequency of occurrence of Saccharomyces cerevisiae populations and their respective mtDNA restriction profiles from three vats of fermentation, at the beginning, middle and end of the period for cachaça production.

\begin{tabular}{|c|c|c|c|c|c|c|}
\hline \multirow[b]{3}{*}{ Period } & \multicolumn{6}{|c|}{ Morphotypes } \\
\hline & \multicolumn{3}{|c|}{$\begin{array}{l}\text { Plain texture and } \\
\text { regular margin }\end{array}$} & \multicolumn{3}{|c|}{$\begin{array}{l}\text { Rough texture and } \\
\text { irregular margin }\end{array}$} \\
\hline & Vat A & Vat B & VatC & Vat A & Vat B & Vat C \\
\hline Beginning & $\begin{array}{l}221 \text { (II)* } \\
63 \text { (I) }\end{array}$ & $\begin{array}{l}33.9(\mathrm{I}) \\
237.3(\mathrm{II}) \\
67.8(\mathrm{~V})\end{array}$ & $\begin{array}{l}267 \text { (II) } \\
33 \text { (IX) }\end{array}$ & - & - & - \\
\hline Middle & $\begin{array}{l}5.58 \text { (II) } \\
0.62 \text { (III) }\end{array}$ & $\begin{array}{l}3.05 \text { (II) } \\
0.38(\mathrm{VI}) \\
0.38(\mathrm{VII}) \\
0.38(\mathrm{X})\end{array}$ & $\begin{array}{l}0.15 \text { (II) } \\
0.05 \text { (III) } \\
0.20 \text { (IV) } \\
0.05 \text { (VI) } \\
0.05 \text { (XI) }\end{array}$ & $\leq 0.1$ (IV) & $\leq 0.1$ (IV) & $\leq 0.1$ (IV) \\
\hline End & $\begin{array}{l}0.69 \text { (II) } \\
0.58(\mathrm{IV})\end{array}$ & $\begin{array}{l}0.47 \text { (II) } \\
0.24 \text { (IV) } \\
0.12 \text { (VI) } \\
0.12 \text { (VIII) } \\
0.24 \text { (IX) } \\
0.12 \text { (X) }\end{array}$ & 300 (XII) & $\leq 0.1$ (IV) & $\leq 0.1$ (IV) & - \\
\hline
\end{tabular}

*No. of isolates (mtDNA restriction profiles); values expressed as $10^{7} \mathrm{cfu} \mathrm{ml}^{-1}$.

and the end of the period; by clusters ' $e$ ' and ' $\mathrm{g}$ ' (vat $\mathrm{B}$, isolates from the beginning and the end of the period); and by clusters ' $i$ ' and ' $\mathrm{j}$ ' (vat $\mathrm{C}$, isolates from the beginning and the middle of the period). The isolates with mtDNA pattern XII, occurring only in vat C, corresponding to commercial bakery yeast, grouped in cluster 'k' (Fig. 3, vat C). Pattern XII isolates represented the PCR profiles 40 and 41 , with approximately $70 \%$ similarity to each other.

Some of the advantages reported for the use of the RAPD and PCR fingerprinting over other molecular techniques for the analysis of populations are the small quantities of template DNA, simplicity and speed of execution, and the relatively low costs involved, all these aspects that allow to work with large number of polymorphic loci randomly sampled across the whole genome (3). Due to the multilocus nature of the RAPD-PCR marker, this method can be both useful and appropriate to estimate intraspecific diversity. The aspects in the method that are considered difficult to deal with are the relative lack of reproducibility of the banding patterns, the need for several reactions with different primers (the RAPDPCR discrimination power depends highly on

vat A. Cluster 'c' was composed by five different molecular profiles, but most isolates corresponded to pattern II of the mtDNA-RFLP analysis. Cluster 'd' corresponded to five molecular profiles represented by 10 isolates with approximately $70 \%$ similarity. These isolates were obtained from the end of the cachaça production period. The number of isolates sharing the same molecular profiles ( $100 \%$ similarity), indicative of clonality, were higher in clusters 'c' and 'd', respectively, when compared to cluster 'a' (Fig. 3, vat A).

In vat $\mathrm{B}$, three major clusters ('e', ' $\mathrm{f}$ ', and 'g') were formed with 14 distinct molecular profiles ( 34 isolates), and in vat $C$, four clusters ('h', 'i', 'j' and 'k') were visualized (31 isolates) (Fig. 3). The general behavior of the $S$. cerevisiae populations described for vat A was also observable for the populations of vats B and $\mathrm{C}$, where isolates from the same period, in general, had similarity somewhere between 70 and $75 \%$ (Fig. 3). The same could be observed for clusters ' $\mathrm{i}$ ', ' $\mathrm{j}$ ' and ' $\mathrm{k}$ ' (vat C). Isolates grouped in cluster ' $\mathrm{i}$ ' (vat C) had the same mtDNA-RFLP profile. Strain UFMG-A2249 did not share any similarity with the other isolates, and generated the single-strain cluster ' $h$ ' (Fig. 3, vat C). The similarity between isolates originated from the same vat but from different periods, on the other hand, decreased to approximately $50 \%$ or less, as can be exemplified by clusters 'c' and ' $\mathrm{d}$ ' (vat A), which were generated respectively with isolates from the middle the primers used), and the need for statistical analysis in order to achieve data meaningfulness (3).

In previous works on the genetic diversity of $S$. cerevisiae prevalent in the fermentation for the production of cachaça, Pataro et al. (12), employing PFGE and PCR fingerprint analysis, found high degrees of genetic polymorphism among isolates from three different distilleries and also among strains isolated from the same vat at different fermentation periods. Guerra $e t$ $a l$. (5) also observed a high molecular diversity among the $S$. cerevisiae isolates, using PFGE, during the daily cycles of cachaça production. However, the authors showed that the RAPD-PCR profiles had few differences among the isolates, suggesting that they were closely related.

In the present work, we isolated 10 colonies of the prevalent morphotype of S. cerevisiae from each of three individual vats from the same distillery, sampled at different moments during the fermentation season (at the beginning, the middle and at the end). Our results of RAPD and PCR fingerprinting analysis showed that the technique allowed the profiling of related yeast isolates, with a good power to genetically discriminate closely related indigenous yeast strains (as indicated by the existence of 41 profiles among 97 isolates), and otherwise, revealing strain families (clusters, $\sim 70 \%$ similarity) according to their origin during the production period (Fig. 3). 


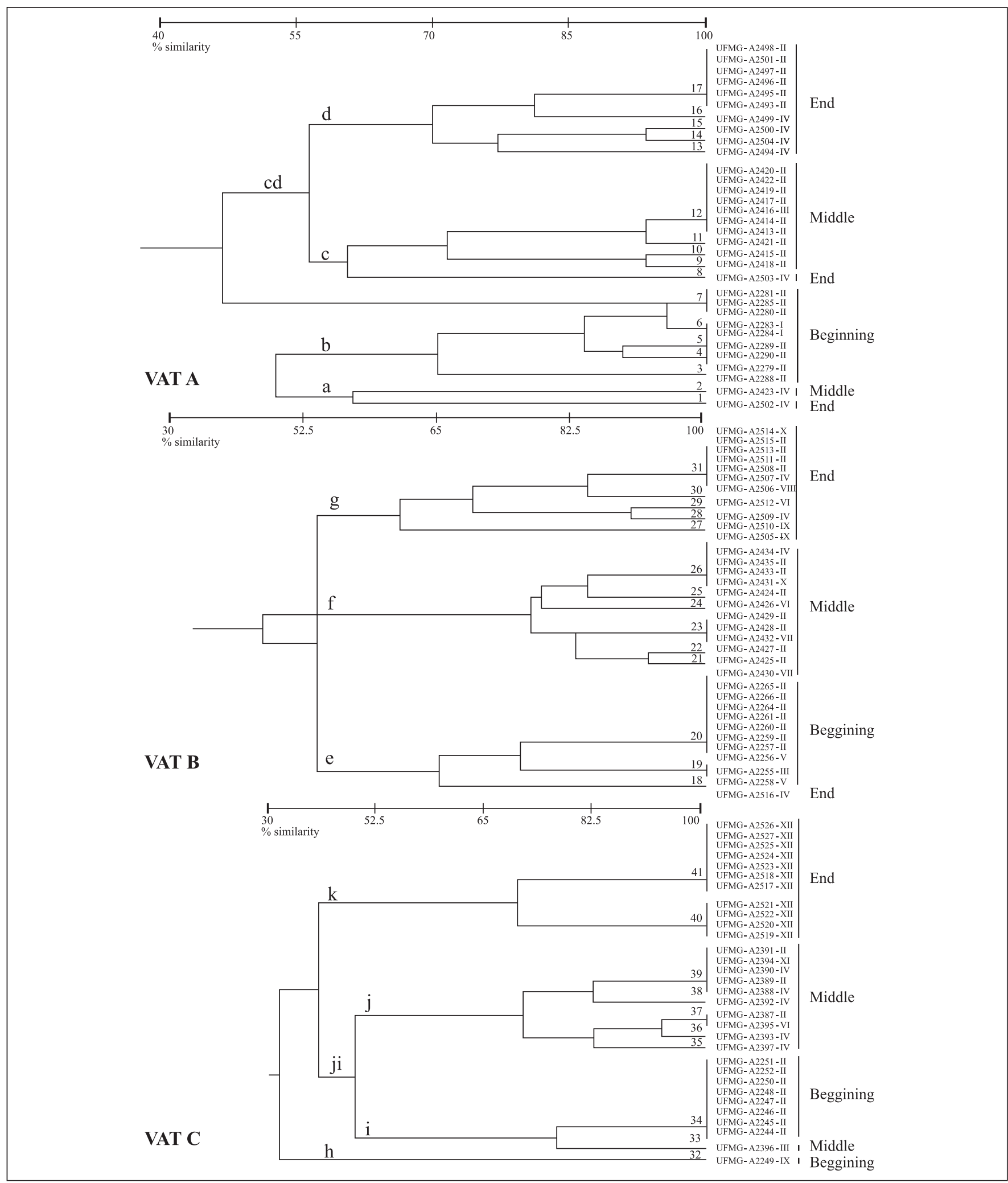

Figure 3. Dendrogram of the Saccharomyces cerevisiae strains based on the RAPD and PCR fingerprinting profiles obtained by primers OPA1 and EI1, respectively. Roman numerals indicate mtDNA restriction patterns type shared by several strains. 
The genotypic diversity during the cachaça fermentation season strongly indicates the necessity to employ effective methods to differentiate $S$. cerevisiae strains. The use of the mtDNA-RFLP, RAPD and PCR fingerprinting analysis to monitor S. cerevisiae revealed a high genetic polymorphism among the isolates from the same vat, from different vats of the same distillery, and among isolates sampled at distinct moments of the annual period of production of the artisanal cachaça. Our results are in accordance with those observed in different previous population studies on ecology and genetic structure of indigenous yeast populations of wineries, indicating a high level of polymorphism in the structure of the nuclear and mitochondrial genomes $(3,5,6,12,14,16,18,21,22)$.

The methods employed here have applicability, being informative on distinct aspects, peculiar to the genetic structure of the population and subpopulations under study. mtDNARFLP was accurate in discriminating strains, fast to execute, easy to perform, reliable and economic. Apart from this, the data generated were easy to interpret (14). On the other hand, the RAPD-PCR technique, although demanding careful and laborious procedures for clustering analysis and for estimation of similarity, was informative on the genetic relatedness among the isolates.

\section{ACKNOWLEDGEMENTS}

We thank the financial support from the Fundação de Amparo a Pesquisa do Estado de Minas Gerais (FAPEMIG), Conselho Nacional de Desenvolvimento Científico e Tecnológico (CNPq), Coordenação de Aperfeiçoamento de Pessoal de Nível Superior (CAPES). We also thank Rodrigo Redondo and Maria Rosa Quaresma Bomfim for their help during this work.

\section{RESUMO}

\section{Monitoramento das populações de Saccharomyces cerevisiae pela análise de restrição do mtDNA e outros métodos de tipagem molecular durante a fermentação espontânea para a produção da cachaça artesanal}

Um estudo ecológico das populações de Saccharomyces cerevisiae em fermentações espontâneas foi conduzido em três dornas de uma destilaria de cachaça em Minas Gerais, Brasil. Noventa e sete isolados foram coletados no início, meio e final do período de produção, e identificados por métodos padrões. A diferenciação entre as linhagens isoladas de $S$. cerevisiae indígenas foi feita pela analise de restrição do DNA mitocondrial (mtDNA), RAPD-PCR, e PCR por impressão digital do DNA utilizando um iniciador complementar a sítios de processamento de íntron. As análises dos perfis de restrição do mtDNA mostraram a ocorrência de 12 perfis diferentes, sendo 11 correspondentes as leveduras indígenas (I ao XI) e um (XII) a uma linhagem comercial de levedura de panificação. Linhagens com o perfil II (53,6\% da população) e o perfil IV estiveram presentes em todas as dornas. A linhagem com perfil IV aumentou do meio para o final do período de fermentação, alcançando proporções próximas a aquelas encontradas para a linhagem com o perfil II. Os métodos baseados em PCR permitiram a diferenciação de 41 perfis moleculares. Ambos os métodos mostraram flutuações populacionais nas linhagens de S. cerevisiae durante o período de produção da cachaça e entre as diferentes dornas da destilaria.

Palavras-chave: Saccharomyces cerevisiae, cachaça, fermentação, diversidade molecular

\section{REFERENCES}

1. De Barros Lopes, M.; Soden, A.; Martens, A.L.; Henschke, P.A.; Langridge, P. (1996). PCR differentiation of commercial yeast strains using intron splice site primers. Appl.Environ. Microbiol., 62, 45144520 .

2. De Barros Lopes, M.; Soden, A.; Martens, A.L.; Henschke, P.A.; Langridge, P. (1998). Differentiation and species identification of yeast using PCR. Int. J. Syst. Bacteriol., 48, 279-286.

3. Fernández-Espinar, M.T.; López, V.; Ramón, D.; Bartra, E.; Querol, A. (2001). Study of authenticity of commercial wine yeast strains by molecular techniques. Int. J. Food Microbiol., 70, 1-10.

4. Gomes, L.H.; Duarte, K.M.R.; Argueso, R.L.; Echeverrigaray, S.; Tavares, F.C.A. (2000). Methods for yeast characterization from industrial products. Food Microbiol., 17, 217-223.

5. Guerra, J.B.; Araújo, R.A.C.; Pataro, C.; Franco, G.R.; Moreira, E.S.A.; Mendonça-Hagler, L.C.; Rosa, C.A. (2001). Genetic diversity of Saccharomyces cerevisiae strains during the $24 \mathrm{~h}$ fermentative cycle for the production of the artisanal Brazilian cachaça. Lett. Appl. Microbiol., 33, 106-111.

6. Guillamón, J.M.; Barrio, E.; Querol, A. (1996). Characterization of wine yeast strains of the Saccharomyces genus on the basis of molecular markers: relationships between genetic distance and geographic or ecological origin, Syst. Appl. Microbiol., 19, 122132 .

7. Kurtzman, C.P.; Fell, J.W. (1998). The Yeasts: A taxonomic study. $4^{r d}$. Elsevier Science Publishers, Amsterdam.

8. López, V.; Querol, A.; Ramón, D.; Fernández-Espinar, M.T. (2001). A simplified procedure to analyse mitochondrial DNA from industrial yeast. Int. J. Food Microbiol., 68, 75-81.

9. Morais, P.B.; Rosa, C.A.; Linardi, V.R.; Pataro, C.; Maia, A.B.R.A. (1997). Characterization and succession of yeast populations associated with spontaneous fermentation for Brazilian sugar-cane 'aguardente' production. World J. Microbiol. Biotech., 13, 241-243.

10. Oliveira, E.S.; Rosa, C.A.; Morgano, M.A.; Serra, G.E. Fermentation characteristics as criteria for selection of cachaça yeast. (2004). World J. Microbiol. Biotech., 20, 19-24.

11. Oliveira, E.S.; Cardello, H.M.B.; Jerônimo, E.M.; Souza, E.L.R.; Serra, G.E. (2005). The influence of different yeasts on the fermentation, composition and sensory quality of cachaça. World J. Microbiol. Biotech., 21, 707-715.

12. Pataro, C.; Guerra, J.B.; Petrillo-Peixoto, M.L.; Mendonça-Hagler, L.C.; Linardi, V.R.; Rosa, C.A. (2000). Yeast communities and karyotype polymorphism of Saccharomyces cerevisiae strains associated with artisanal fermentations in Brazil. J. Appl. Microbiol., 89, 24-31. 
13. Pataro, C.; Guerra, J.B.; Neves, M.J.; Pimentel, P.F., Rosa, C.A. (2002). Trehalose accumulation, invertase activity and physiological characteristics of yeasts isolated from $24 \mathrm{~h}$ fermentative cycles during the production of artisanal Brazilian cachaça. Braz. J. Microbiol., 33, 202-208.

14. Querol, A.; Barrio, E.; Huerta,T.; Ramón, D. Molecular monitoring of wine fermentations conducted by active dry yeast strains. (1992). Appl. Environ. Microbiol., 58, 2948-2953.

15. Querol, A.; Barrio, E.; Ramón, D. (1992). A comparative study of different methods of yeast strain characterizaton. Syst. Appl. Microbiol., 15, 439-446.

16. Querol, A.; Barrio, E.; Ramón, D. (194). Population dynamics of natural Saccharomyces strains during wine fermentation. Int. J. Food Microbiol., 21, 315-323.

17. Querol, A.; Ramón, D. (1996). The application of molecular techniques in wine microbiology. Trends Food Sci. Technol., 7, 7378 .
18. Sabaté, J.; Cano, J.; Querol, A.; Guillamón, J.M. (1998). Diversity of Saccharomyces cerevisiae in wine fermetations: analysis for two consecutive years. Lett. Appl. Microbiol., 26, 452-455.

19. Schwan, R.F.; Mendonça, A.T.; Silva Júnior, J.J.; Rodrigues, V.; Wheals, A.E. (2001). Microbiology and physiology of Cachaça (Aguardente) fermentations. Antonie van Leeuwenhoek, 79, 86-96.

20. Schuller, D.; Valero, E.; Dequin, S.; Casal, M. (2004). Survey of molecular methods for the typing of wine yeast strains. FEMS Microbiol. Lett., 231, 19-26.

21. Torija, M.J.; Roses, N.; Poblet, M.; Guillamón, J.M.; Mas, A. (2001). Yeast population dynamics in spontaneous fermentations: Comparison between two different wine-producing areas over a period of three years. Antonie van Leeuwenhoek, 79, 345-352.

22. Versavaud, A.; Courcoux, P.; Roulland. C.; Dulau, L.; Hallet, J. (1995). Genetic diversity and geographical distribution of wild Saccharomyces cerevisiae strains from the wine-producing area of Charents, France. Appl. Environ. Microbiol., 61, 3521-3529. 